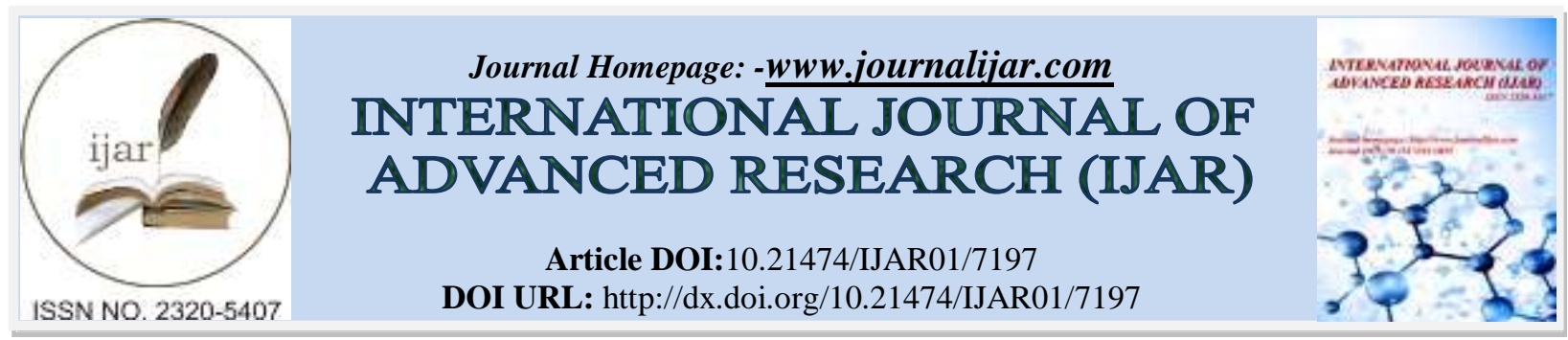

RESEARCH ARTICLE

\title{
A STUDY OF CORRELATION BETWEEN TOTAL CHOLESTEROL, TOTAL BILIRUBIN, CALCIUM AND INORGANIC PHOSPHATE OF GALLSTONE AND SERA OF THE STONE FORMERS.
}

1. Demonstrator ofbiochemistry,gmc,assam.

2. Professor and hod,deptof biochemistry,gmc,assam.

3. Assistant professor of surgery,amc,assam.

\section{Manuscript Info}

Manuscript History

Received: 03 April 2018

Final Accepted: 05 May 2018

Published: June 2018

\section{Abstract}

Gallbladder cancer appears to be a late complication of cholelithiasis, and in our part of the world the incidence of gallbladder cancer is very high. A thorough understanding on gallstone disease thus becomes paramount. The major chemical components of gallstones are cholesterol, bilirubin and calcium. In our study we have chemically analyzed the 40 gallstones obtained from patients who had undergone cholecystectomy and quantitatively analyzed the parameters which are total cholesterol, total bilirubin, calcium and inorganic phosphate both in the serum of the stone formers and in their respective gallstones, and determined the correlation if any present between the serum and the stone values. In our study we found that majority of the gallstones were pigment gallstones, followed by mixed gallstone and cholesterol gallstones. We have found a positive correlation between total bilirubin in serum and total bilirubin in pigment gallstones. Which has led us to a conclusion that hyperbilirubinemia play an important role in the formation of pigment gallstones and that detection of hyperbilirubinemia in a suspect group must further be investigated for asymptomatic gallstone disease.

Copy Right, IJAR, 2018,. All rights reserved.

\section{Introduction:-}

Cholelithiasis is one of the most frequent gastro-intestinal disorders in the westernized countries including Europe (1) and with newer methods of research and better access to healthcare the notion of cholelithiasis being less frequent in developing countries is slowly fading and India also projects a similar scenario. Studies have shown that Indian females shoulders the burden of 10-22\% of the worldwide prevalence of gallstones among females.(2)(3). Gallstones are the commonest associated risk factor with Gallbladder cancer, and appear to occur at a younger age in India. The problem of high incidence of gallstones with a rising rate of Gallbladder cancer is a uniquely Indian problem. The annual age adjusted incidence rates of Gallbladder cancer in Chile which is acknowledged to have a high incidence of gallbladder cancer is about 7 cases per 100,000 persons per year where as the same rate for females in Kamrup is almost 14 (4). To tackle this problem a thorough understanding of the disease becomes a necessity. 
Chemical analysis of biliary calculi obtained from patients after cholecystectomy has revealed that gallstone consists mainly of calcium salts of cholesterol and bilirubin. Quantitative analysis of principal constituents of gallstones such as cholesterol, bilirubin, inorganic phosphate and calcium is very well studied (5). But there remains a dearth of studies that correlates the same constituents between the serum of gallstone patients and the gallstones. In our study we have endeavored to study the basic biochemical components of the gallstones constituting total cholesterol, total bilirubin, calcium and inorganic phosphate and we have studied the same in the serum of the patients and to study the correlation if any between the composition of gallstones and sera of the stone formers in respect of the parameters analysed. This question is important from both clinical and scientific view points.

\section{Materials and methods:-}

The present study was carried in 40 patients suffering from cholelithiasis and underwent cholecystectomy in the department of surgery, Assam Medical College and Hospital. All the biochemical parameters was carried out in the department of biochemistry and advanced clinical biochemistry laboratory,over a term of one year.

Under all aseptic and antiseptic conditions $5 \mathrm{ml}$ of blood sample was collected from each subject from a suitable peripheral vein (preferably antecubital vein) by venipuncture using a sterile disposable syringe into a sterile empty vial. The blood samples were collected in the morning prior to the cholecystectomy. The sample was then allowed to stand for some time and centrifuged at $5000 \mathrm{rpm}$ for ten minutes soon after clot formation for separation of serum. This serum was used for estimation of the parameters.

Preparation of Gallstones(6):

The gallstones were collected after cholecystectomy performed either by laparoscopically or by the open route. All the gallstones were identically processed. The gallstones were washed with distilled water and air dried. The gallstones were pulverized in a mortar and pestle and dessicated to a constant weight. The mass of each stone as well as it's powder was measured using an analytical scale. To determine total cholesterol and total bilirubin $30 \mathrm{mg}$ of the dried gallstone powder was taken in a test tube and dissolved in $3 \mathrm{ml}$ of acidified methanol-chloroform mixture $(1: 1 \mathrm{v} / \mathrm{v})$ containing $1 \%$ of $1 \mathrm{~N} \mathrm{HCL} \mathrm{(7).} \mathrm{The} \mathrm{tube} \mathrm{was} \mathrm{kept} \mathrm{in} \mathrm{boiling} \mathrm{water} \mathrm{bath} \mathrm{for} \mathrm{two} \mathrm{minutes.} \mathrm{The} \mathrm{stone} \mathrm{solution}$ thus obtained was used for determination of total cholesterol and total bilirubin. To determine calcium and inorganic phosphate, $30 \mathrm{mg}$ of the gallstone powder was dissolved in $3 \mathrm{ml} \mathrm{1N} \mathrm{HCL}$ in a graduated $10 \mathrm{ml}$ tube and its final volume was made upto $10 \mathrm{ml}$ with distilled water. The tube was kept in boiling water bath for 1 hour. The stone solution thus obtained was used to determine calcium and inorganic phosphate.. The gallstone powder which was insoluble, was dried, weighed and designated as residue which was no further analyzed. Compositions were expressed as milligrams per gram of dry initial weight. All the tests were done by using enzymatic colorimetric methods, as described.

Total cholesterol was done using the CHOD/PAP principle (8)(9). Calcium was done using the principle of OCPC method (10)(11). Inorganic phosphate was done using the principle of Molybdalate U.V metho(12). Total bilirubin was estimated using the Mod. Jendrasik\&Grof's method (13). Triton X was required to prevent the precipitation present.All the kits were provided by Coral Clinical Systems by Tulip Diagnostics.

\section{Statistical Analysis:-}

All the datas were analyzed using Microsoft Office Excel 2007. Distribution of variable was evaluated by calculating the mean and standard deviation. The difference between means was evaluated by using the t-test. Correlation between the parameters was evaluated by using the Pearson correlation formula and it's p-value calculated to determine the statistical significance.

When the p-value was $<0.05$, it was considered to be statistically significant. When the p-value was $>0.05$, it was considered as statistically insignificant.

\section{Results and Discussion:-}

AGE: in the present study the age incidence ranged from $24-57$ years. The highest number of cases was recorded in the age group $41-50$ years $(n=14)$, followed by the age group $51-59$ years $(n=12)$; and the least number of cases in 21-30 age group ( $\mathrm{n}=5$ ) cases. The finding from our study is comparable with that of C.S.Pundir et al (5), Kafia.M.Shareefetal (14), and P.Jaganadharaoetal (15), all these studies observed an increased incidence of gallstones irrespective of the type of gallstones in the age group of 41-50 years; while C.S. Santosh et al(16) and a 
study conducted by Md.A.Taher (17) recorded an increased number of cholelithiasis cases in the age group 51-65 years.

\section{Sex Distribution:-}

In the present study out of 40 patients with gallstones, 24 of them were female comprising $60 \%$ of the study population, while $16(40 \%)$ of the patients were male. The ratio of male:female observed was 1:1.5. Study by Das Biswajitetal (18)has observed a male to female ratio of 1:3.8, while a study conducted by Goswami.M (19) at Guwahati observed a ratio of 1:2.5. A male: female ratio of 1:8 was recorded by Kafia.M.Shareefetal (14), in a study done in Libiya

\section{BMI:}

In the present study, the vast majority of subjects afflicted with gallstone disease had a BMI ranging between overweight at $42.5 \%$, and normal BMI at $35 \% \%$, while very low percentage of subjects were categorized as obese, $7.5 \%$, and $15 \%$ were underweight

\section{TYPE OF STONE:}

In our study we followed the Japanese classification of gallstones(20)(21) in which pure cholesterol stones were those stones that had a cholesterol content $\geq 70 \%$, mixed gallstones were those stones that had cholesterol content more that $30 \%$ but less than $70 \%$; and pigment stones that had cholesterol content less than $30 \%$. The cholesterol content was based on the total dry weight of the respective stones.

In our study population of 40 we found that pigment gallstones were the most abundant at $n=16(40 \%)$, followed by mixed gallstones $n=13$ (32.5\%), and cholesterol gallstones were least frequently seen with $n=11(27.5 \%)$.

P.Chandranetal (6) observed the highest number of gallstones to fall under mixed gallstones $(\mathrm{n}=76)$, closely followed by pigment gallstones $(n=72)$, while cholesterol gallstones were only $(n=52)$. Mhd.H.Faris.S. etal (22) observed in their study that the highest number of stones were pigment gallstones $(n=48)$, followed by mixed gallstones $(n=30)$, and cholesterol gallstones $(n=16)$. The study by C.S. Santoshetal (23) observed that mixed gallstones were highest in their study with $(n=36)$, followed by cholesterol gallstones $(n=9)$ and pigment gallstones $(\mathrm{n}=5)$.

Table 1:- quantitative analysis of the parameters in cholesterol gallstones and in serum of the patients.

\begin{tabular}{|c|c|c|c|c|c|c|c|c|}
\hline \multirow{2}{*}{$\begin{array}{l}\text { Type } \quad \text { Of } \\
\text { Stone }\end{array}$} & \multicolumn{2}{|c|}{ Total Cholesterol } & \multicolumn{2}{|c|}{ T. Bilirubin } & \multicolumn{2}{|l|}{ Calcium } & \multicolumn{2}{|c|}{ Inorganic Phosphate } \\
\hline & $\begin{array}{l}\text { In Serum } \\
\mathrm{mg} / \mathrm{dl}\end{array}$ & $\begin{array}{l}\text { In Stone } \\
\mathrm{mg} / \mathrm{dl}\end{array}$ & $\begin{array}{l}\text { In Serum } \\
\mathrm{mg} / \mathrm{dl}\end{array}$ & $\begin{array}{l}\text { In Stone } \\
\mathrm{mg} / \mathrm{dl}\end{array}$ & $\begin{array}{l}\text { In Serum } \\
\mathrm{mg} / \mathrm{dl}\end{array}$ & $\begin{array}{l}\text { In Stone } \\
\mathrm{mg} / \mathrm{dl}\end{array}$ & $\begin{array}{l}\text { In Serum } \\
\mathrm{mg} / \mathrm{dl}\end{array}$ & $\begin{array}{l}\text { In Stone } \\
\mathrm{mg} / \mathrm{dl}\end{array}$ \\
\hline $\begin{array}{l}\text { Cholesterol } \\
\text { gallstone }\end{array}$ & $\begin{array}{ll}208.27 & \pm \\
35.60 & \end{array}$ & $\begin{array}{l}784.36 \pm \\
30.85\end{array}$ & $\begin{array}{ll}0.79 & \pm \\
0.18 & \end{array}$ & $\begin{array}{ll}1.38 & \pm \\
0.22 & \end{array}$ & $\begin{array}{ll}8.57 & \pm \\
0.36 & \end{array}$ & $\begin{array}{ll}5.37 & \pm \\
1.0 & \end{array}$ & $\begin{array}{ll}4.97 & \pm \\
0.68 & \end{array}$ & $12.41 \pm 0.87$ \\
\hline $\begin{array}{l}\text { Correlation } \\
\text { Coefficient } \\
\text { (r) }\end{array}$ & 0.120 & & 0.029 & & 0.290 & & 0.080 & \\
\hline P-Value & $>0.05$ & & $>0.05$ & & $>0.05$ & & $>0.05$ & \\
\hline
\end{tabular}

Table 2:- Quantitative analysis of the parameters in mixed gallstones and in serum of the patients.

\begin{tabular}{|c|c|c|c|c|c|c|c|c|}
\hline \multirow{2}{*}{$\begin{array}{ll}\text { Type } & \text { Of } \\
\text { Stone } & \end{array}$} & \multicolumn{2}{|c|}{ Total Cholesterol } & \multicolumn{2}{|c|}{ T. Bilirubin } & \multicolumn{2}{|l|}{ Calcium } & \multicolumn{2}{|c|}{ Inorganic Phosphate } \\
\hline & $\begin{array}{l}\text { In Serum } \\
\mathrm{mg} / \mathrm{dl}\end{array}$ & $\begin{array}{l}\text { In Stone } \\
\mathrm{mg} / \mathrm{dl}\end{array}$ & $\begin{array}{l}\text { In Serum } \\
\mathrm{mg} / \mathrm{dl}\end{array}$ & $\begin{array}{l}\text { In Stone } \\
\mathrm{mg} / \mathrm{dl}\end{array}$ & $\begin{array}{l}\text { In Serum } \\
\mathrm{mg} / \mathrm{dl}\end{array}$ & $\begin{array}{l}\text { In Stone } \\
\mathrm{mg} / \mathrm{dl}\end{array}$ & $\begin{array}{l}\text { In Serum } \\
\mathrm{mg} / \mathrm{dl}\end{array}$ & $\begin{array}{l}\text { In Stone } \\
\mathrm{mg} / \mathrm{dl}\end{array}$ \\
\hline $\begin{array}{l}\text { Mixed } \\
\text { gallstone }\end{array}$ & $\begin{array}{l}214.08 \quad \pm \\
31.76\end{array}$ & $\begin{array}{l}580.54 \pm \\
43.31\end{array}$ & $\begin{array}{l}1.12 \\
0,25\end{array}$ & $\begin{array}{ll}3.7 & \pm \\
0.38 & \end{array}$ & $\begin{array}{ll}7.69 & \pm \\
0.31 & \end{array}$ & $\begin{array}{ll}8.22 & \pm \\
1.88 & \end{array}$ & $\begin{array}{ll}4.82 & \pm \\
0.37\end{array}$ & $9.34 \pm 1.08$ \\
\hline $\begin{array}{l}\text { Correlation } \\
\text { Coefficient }\end{array}$ & \multicolumn{2}{|l|}{-0.012} & \multicolumn{2}{|l|}{-0.279} & \multicolumn{2}{|l|}{0.025} & \multicolumn{2}{|l|}{0.188} \\
\hline P-Value & \multicolumn{2}{|l|}{$>0.05$} & \multicolumn{2}{|l|}{$>0.05$} & \multicolumn{2}{|l|}{$>0.05$} & \multicolumn{2}{|l|}{$>0.05$} \\
\hline
\end{tabular}


Table 3:- Quantitative analysis of the parameters in pigment gallstones and in serum of the patients.

\begin{tabular}{|c|c|c|c|c|c|c|c|c|}
\hline \multirow{2}{*}{$\begin{array}{l}\text { Type } \quad \text { Of } \\
\text { Stone }\end{array}$} & \multicolumn{2}{|c|}{ Total Cholesterol } & \multicolumn{2}{|l|}{ T. Bilirubin } & \multicolumn{2}{|l|}{ Calcium } & \multicolumn{2}{|c|}{ Inorganic Phosphate } \\
\hline & $\begin{array}{l}\text { In Serum } \\
\mathrm{mg} / \mathrm{dl}\end{array}$ & $\begin{array}{l}\text { In Stone } \\
\mathrm{mg} / \mathrm{dl}\end{array}$ & $\begin{array}{l}\text { In Serum } \\
\mathrm{mg} / \mathrm{dl}\end{array}$ & $\begin{array}{l}\text { In Stone } \\
\mathrm{mg} / \mathrm{dl}\end{array}$ & $\begin{array}{l}\text { In Serum } \\
\mathrm{mg} / \mathrm{dl}\end{array}$ & $\begin{array}{l}\text { In Stone } \\
\mathrm{mg} / \mathrm{dl}\end{array}$ & $\begin{array}{l}\text { In Serum } \\
\mathrm{mg} / \mathrm{dl}\end{array}$ & $\begin{array}{l}\text { In Stone } \\
\mathrm{mg} / \mathrm{dl}\end{array}$ \\
\hline $\begin{array}{l}\text { Pigment } \\
\text { gallstone }\end{array}$ & $\begin{array}{ll}186.56 & \pm \\
35.33 & \end{array}$ & $\begin{array}{ll}264 & \pm \\
38.27 & \end{array}$ & $\begin{array}{l}1.47 \quad \pm \\
0.57\end{array}$ & $\begin{array}{ll}5.81 & \pm \\
0.79 & \end{array}$ & $\begin{array}{ll}8.33 & \pm \\
0.66 & \end{array}$ & $\begin{array}{l}9.14 \\
1.24\end{array}$ & $\begin{array}{l}3.49 \\
0.52\end{array}$ & $4.04 \pm 0.54$ \\
\hline $\begin{array}{l}\text { Correlation } \\
\text { Coefficient }\end{array}$ & \multicolumn{2}{|l|}{-0.114} & \multicolumn{2}{|l|}{0.563} & \multicolumn{2}{|l|}{-0.078} & \multicolumn{2}{|l|}{-0.040} \\
\hline P-Value & \multicolumn{2}{|l|}{$>0.05$} & \multicolumn{2}{|l|}{$<0.05$} & \multicolumn{2}{|l|}{$>0.05$} & \multicolumn{2}{|l|}{$>0.05$} \\
\hline
\end{tabular}

On interpreting our data to study the correlation, if any present, between total cholesterol, total bilirubin, calcium and inorganic phosphate in the serum and the respective gallstones of the patients, no significant correlation was observed in cholesterol gallstone group, and the mixed gallstone group.

In patients suffering from pigment gallstones, we observed a significant positive correlation of total bilirubin between serum and respective gallstone of the patients. This implies that a rise in serum total bilirubin will increase the concentration of bilirubin in the pigment gallstones.,

An increase in bilirubin, in the serum will subsequently increase the amount of substrate for the endogenous biliary $\beta$-glucuronidasae, which in turn will increase the levels of non-polar monohydogenated unconjugated bilirubin in bile, which may precipitate as insoluble salt with calium in bile and thus lead to the formation of pigment gallstones (24). C.S.Pundiretal (25)K.M.Shareefetal (14), both observed in their studies a positive correlation of total bilirubin in serum and pigment gallstone of the patients. S.Stefan et al (26) observed that subjects having plasma bilirubin in the 10 'thdecile (geometric mean of $1.34 \mathrm{mg} / \mathrm{dl}$ ) have a greater risk of symptomatic gallstone disease.

\section{Conclusion:-}

In the group of patients with pigment gallstones, a significant positive correlation was present between total bilirubin in serum and total bilirubin in pigment gallstones.

It may be concluded that hyperbilirubinemiain vivo, subsequently increase the substrate for the endogenous biliary $\beta$-glucuronidase to act upon, which in turn will increase the amount of monohydrogenated UCB excreated into the bile, greatly exceeding it's solubility in bile and will ultimately precipitate as insoluble salt with calcium and lead to the formation of pigment gallstones.

In our part of the country which shoulders a major share of the global scourge of gallbladder cancer, which in turn is supposedly a late complication of cholelithaisis, detection of hyperbilirubinemia in a suspect group would alarm an alert physician to further investigate if the patient is suffering from asymptomatic gallstone disease and plan early surgical intervention.

\section{References:-}

1. Portincasa P, Di Ciaula A, Grattagliano I. Preventing a mass disease: The case of gallstones disease: Role and competence for family physicians. Korean Journal of Family Medicine. 2016; 37(4):205.

2. .Stinton LM, Shaffer EA. Epidemiology of gallbladder disease: Cholelithiasis and cancer. Gut and Liver. 2012 Apr 15; 6(2):172-87.

3. Everhart JE, Yeh F, Lee ET, Hill MC, Fabsitz R, Howard BV, Welty TK. Prevalence of gallbladder disease in American Indian populations: Findings from the strong heart study. Hepatology. 2002 Jun; 35(6):1507-12.

4. Jun, Mathur AV. Need for Prophylactic Cholecystectomy in silent gall stones in north India. Indian Journal of Surgical Oncology. 2015; 6(3):251-5.

5. Chandran P, Kuchhal NK, Garg P, Pundir CS. An extended chemical analysis of gallstone. Indian Journal of Clinical Biochemistry. 2007 Sep; 22(2):145-50.

6. Chandran P, Kuchhal NK, Garg P, Pundir CS. An extended chemical analysis of gallstone. Indian Journal of Clinical Biochemistry. 2007 Sep; 22(2):145-50.

7. Baron R, Rohrmann C, Lee S, Shuman W, Teefey S. CT evaluation of gallstones in vitro: Correlation with chemical analysis. American Journal of Roentgenology. 1988 Dec; 151(6):1123-8. 
8. Allain CC, Poon LS, Chan CSG, Richmond W, Fu3 PC. EnzymaticDeterminationof total serum cholesterol. CLIN. CHEM. CLINICAL CHEMISTRY. 2004; 204(4):470-5.

9. 1, Flegg HM. Ames award lecture 1972. An investigation of the determination of serum cholesterol by an enzymatic method. Annals of Clinical Biochemistry: An international journal of biochemistry and laboratory medicine. 1973 Jan; 10(1-6):79-84.

10. Gitelman HJ. An improved automated procedure for the determination of calcium in biological specimens. Analytical Biochemistry. 1967; Mar, 18(3):521-31.

11. Baginski ES, Marie SS, Clark WL, Zak B. Direct microdetermination of serum calcium. ClinicaChimicaActa. 1973 Jun; 46(1):46-54.

12. Fiske CH, Subbarow Y. The colorimetric determination of phosphorus. Journal of Biological Chemistry. 1925 Jan 12;66(2):375-400.

13. Jendrassik .L. Grof .P.(1938), Biochem.2,297:81

14. Shareef, KM, Omar LS, Garota SA. Correlation between the chemical components of gallstones and sera of stone formers. Gomal Journal of Medical Sciences. 2009 Jan; 7(1):2-6.

15. Jaraari AM, Jagannadharao JP, Patil TN, Hai A, Awamy HA, El Saeity SO, Kafi EBA, El Hemri MN, Tayesh MF. Quantitative analysis of gallstones in Libyan patients. Libyan Journal of Medicine. 2010 Jan 6; 5.

16. C. S. Santhosh, R. Purantar. "A comparative study of Serum Cholesterol,Bilirubin,Phosphate and Calcium in patients with gallstones and normal persons". Rguhs dissertations: 2006:p-56.

17. Taher MA. International journal of medicine and medical sciences - descriptive study of cholelithiasis with chemical constituents' analysis of gallstones from patients living in baghdad, iraq. International Journal of Medicine and Medical Sciences.2013Jan31;5(1):19-23.

18. Das B, Mallick AK, Rehman A, Samanta S, AhsanM.Quantitative analysis of chemical composition of gallstones in north Indian population ( Rohilkhand region, uttar Pradesh). NJIRM 2014; Vol. 5(4).july-august

19. Goswami, M. An analysis of 160 cholecystectomics at Guwahati.Indian journal of surgery, 1999,2:252-255.

20. Qiao T, Ma R, Luo X, Yang L, Luo Z, Zheng P. The systematic classification of gallbladder stones. PLoS ONE. 2013 Oct 4; 8(10):e74887

21. Kim IS, Myung SJ, Lee SS, Kim MH. Classification and nomenclature of gallstones revisited. Yonsei Medical Journal. 2003; 44(4):561.

22. Mhd.H.F.Shalayel, S. A. Idris, K.E.Elsiddig,A.A.Hamza, m.MHafiz.Biochemical composition of gallstones:Do different genders differ.American journal of biological chemistry.vol.1,No.1,2013,pp.1-6.

23. C.S.Santhosh, R.Purantar."A comparative study of Serum Cholesterol,Bilirubin,Phosphate and Calcium in patients with gallstones and normal persons". Rguhs dissertations:2006:p-64.

24. Vítek L, Carey MC. New pathophysiological concepts underlying pathogenesis of pigment gallstones. Clinics and Research in Hepatology and Gastroenterology. 2012;36(2):122-129. doi:10.1016/j.clinre.2011.08.010.

25. Pundir, C.S., K. Rani, P. Garg, R. Chaudhary, P. Chandran and M. Kumari. Correlation between chemical composition of Biliary Calculi and sera of stone formers. Indian J. Med. Sci., 56: 373-375.

26. Stender S, Frikke-Schmidt R, Nordestgaard BG, Tybjærg-Hansen A. Extreme Bilirubin levels as a causal risk factor for symptomatic gallstone disease. JAMA Internal Medicine. 2013 Jul 8; 173(13):1222. 